\title{
Pre-collisional high pressure metamorphism and nappe tectonics at active continental margins: a numerical simulation
}

\author{
Bernhard Stöckhert ${ }^{1}$ and Taras V. Gerya ${ }^{1,2,3}$ \\ ${ }^{1}$ Institute of Geology, Mineralogy, and Geophysics, Sonderforschungsbereich 526, Ruhr-University, Bochum, Germany; ${ }^{2}$ Institute of \\ Experimental Mineralogy, Chernogolovka, Moscow district, Russia; ${ }^{3}$ Present address: Geologisches Institut, ETH Zürich, Zurich, Switzerland
}

\begin{abstract}
The evolution of a subduction channel and orogenic wedge is simulated in 2D for an active continental margin, with P-T paths being displayed for selected markers. In our simulation, subduction erosion affects the active margin and a structural pattern develops within a few tens of millions of years, with four zones from the trench into the forearc: (i) an accretionary complex of low grade metamorphic sedimentary material, (ii) a wedge of nappes with alternating upper and lower crustal provenance, and minor interleaving of oceanic or hydrated mantle material, (iii) a megascale melange composed of high pressure (HP) and ultra-high pressure (UHP)
\end{abstract}

metamorphic rocks extruded from the subduction channel, and (iv) the upward tilted frontal part of the remaining lid. The $P-T$ paths and time scales correspond to those typically recorded in orogenic belts. The simulation shows that HP/UHP metamorphism of continental crust does not necessarily indicate collision, but that the material can be derived from the active margin by subduction erosion and extruded from the subduction channel beneath the forearc during ongoing subduction.

Terra Nova, 17, 102-110, 2005

\section{Introduction}

Studies on high pressure (HP) and ultra-high pressure (UHP) metamorphic rocks exposed in collisional belts have shown that these units (i) are derived from both continental and oceanic crust, being intermingled on the length scale of nappes, (ii) are frequently associated with hydrated peridotites, (iii) reveal a variable $P-T$ $t$ record, with (iv) narrow time constraints indicating that exhumation rates can be on the order of plate velocity. The $P-T$ paths, the restricted size of the UHP metamorphic slices, and the narrow time constraints favour tectonic models that involve exhumation by forced flow in a subduction channel. Using a set of appropriate flow laws for different crustal and mantle materials, and including progressive hydration of the mantle wedge, we have extended our previous model of a subduction channel (Gerya et al., 2002) to an active continental margin.

It seems to be tacitly assumed by many authors (e.g. Hacker and Liou, 1998; Chopin, 2003) that UHP meta-

Correspondence: Bernhard Stöckhert, Institute of Geology, Mineralogy, and Geophysics, Sonderforschungsbereich 526, Ruhr-University, Bochum, Germany. Tel.: + 49 (0)234 3223227; fax: + 49 (0)234 3214572; e-mail: bernhard.stoeckhert@ ruhr-uni-bochum.de morphic continental crust is derived from the downgoing plate and thus generally indicates collision. Deep burial during collision is accordingly simulated in analogue (e.g. Chemenda et al., 1995) and numerical studies (e.g. Burov et al., 2001). On the contrary, geochronology suggests that UHP metamorphism may have taken place prior to collision (e.g. Eide and Liou, 2000). Furthermore, the limited size of UHP metamorphic slices, for example, in the Alps, and the overall crustal volume available in orogenic belts bearing UHP metamorphic rocks do not support the hypothesis of burial and exhumation of coherent continental crust. The volumetric problems inherent in the palinspastic reconstruction of the Alps, with individual microcontinents separated by oceanic branches, have been lucidly portrayed by Polino et al. (1990). Motivated by these apparent inconsistencies, we present an alternative hypothesis supported by the numerical simulation, which accounts for UHP metamorphism prior to collision, limited size of UHP metamorphic units, and the problem of storage of an appropriate volume of continental crust in present day orogenic belts, as in the Alps.

\section{Numerical approach}

We use a 2-D numerical model (Fig. 1) with a kinematically pre- scribed subducting plate, a surface undergoing erosion and sedimentation, and progressive hydration of the mantle wedge (Gerya et al., 2002; Gerya and Yuen, 2003a). A set of best guess flow laws is used to describe the mechanical behaviour of the materials as a function of depth and temperature. For solving the momentum, continuity and temperature equations, we have employed a 2-D numerical thermomechanical code I2VIS based on finite differences and marker-in-cell technique (Gerya et al., 2000; Gerya and Yuen, 2003b). Details are given in the Supplementary Material, hyaa, Table S1.

\section{Results}

The results of the numerical simulation for one of our reference models (hyaa; Table S1) are visualized in Fig. 2 as a sequence of time slabs: within a few million years from the onset of subduction, subduction erosion starts to remove continental crust from the front of the upper plate. Former upper and lower continental crust becomes wound up in a marble cake-like manner forming a wide wedge beneath the frontal part of the forearc reaching a depth of approximately $\quad 50-70 \mathrm{~km}$. Minor amounts of continental crust are carried further down, to depths of $100 \mathrm{~km}$ and more, into the narrowing subduction channel and partly return 

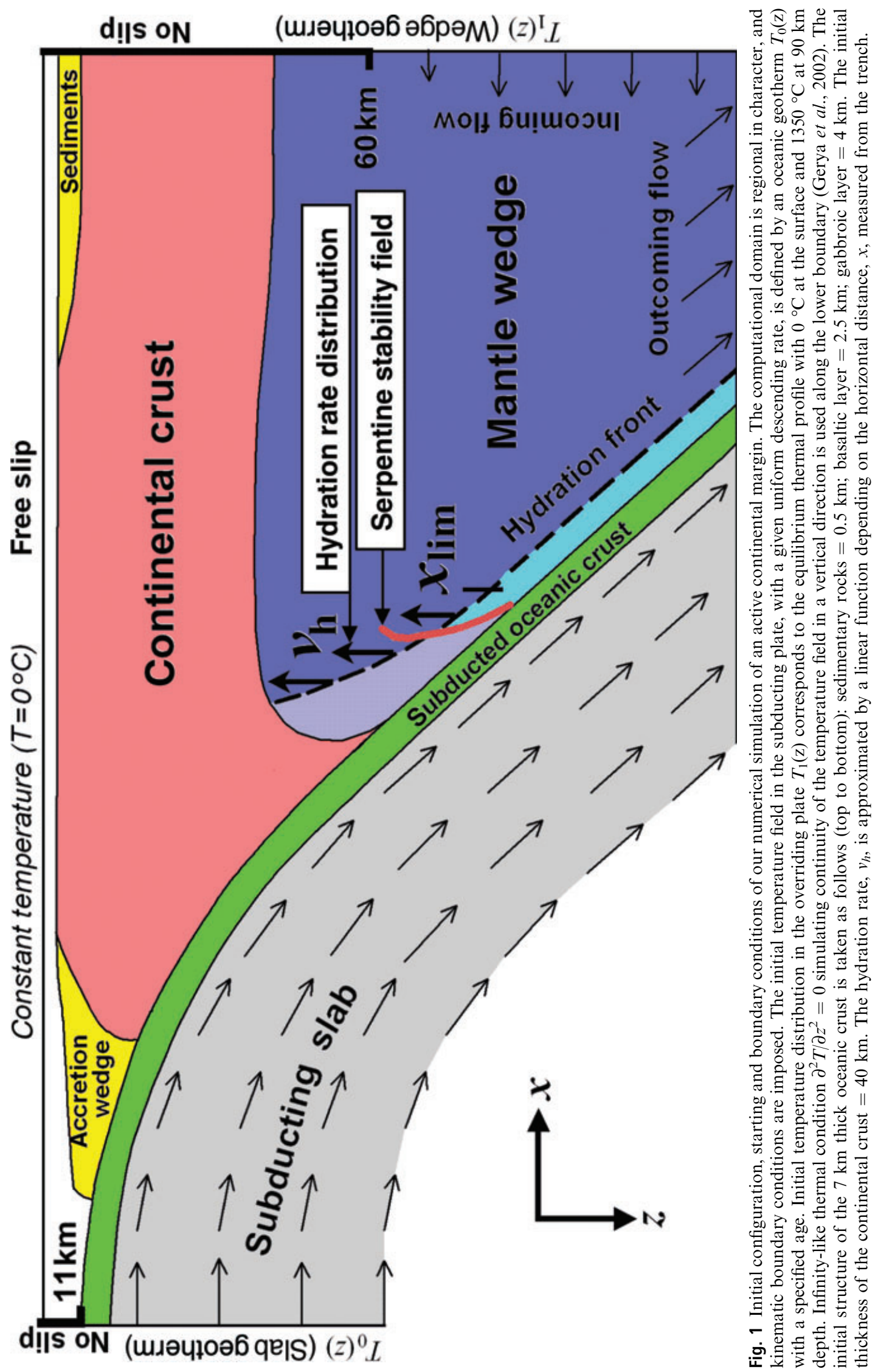
by forced flow, mixing with material derived from the subducted oceanic crust and the hydrated mantle at the hangingwall. These returning HP or UHP metamorphic slices become extruded from the subduction channel forming a mega-scale melange at the landward side of the marble cake wedge. Controlled by the strength of the overlying continental lid, both the wedge and the landward megascale melange progressively warp up and eventually become exposed by erosion. After $30 \mathrm{Myr}$ of subduction with a rate of $3 \mathrm{~cm}$ year $^{-1}$ an active continental margin structure with four distinct zones has developed, which are (landwards from the trench):

1 An accretionary complex of at best low grade metamorphic sedimen- tary material (poorly developed in the model shown here).

2 A wedge of deformed continental crust derived from the front of the overriding active margin by subduction erosion, with medium grade HP metamorphic overprint, wound up and stretched in a marble cake fashion to appear as metamorphic nappes with alternating upper and lower crustal provenance.

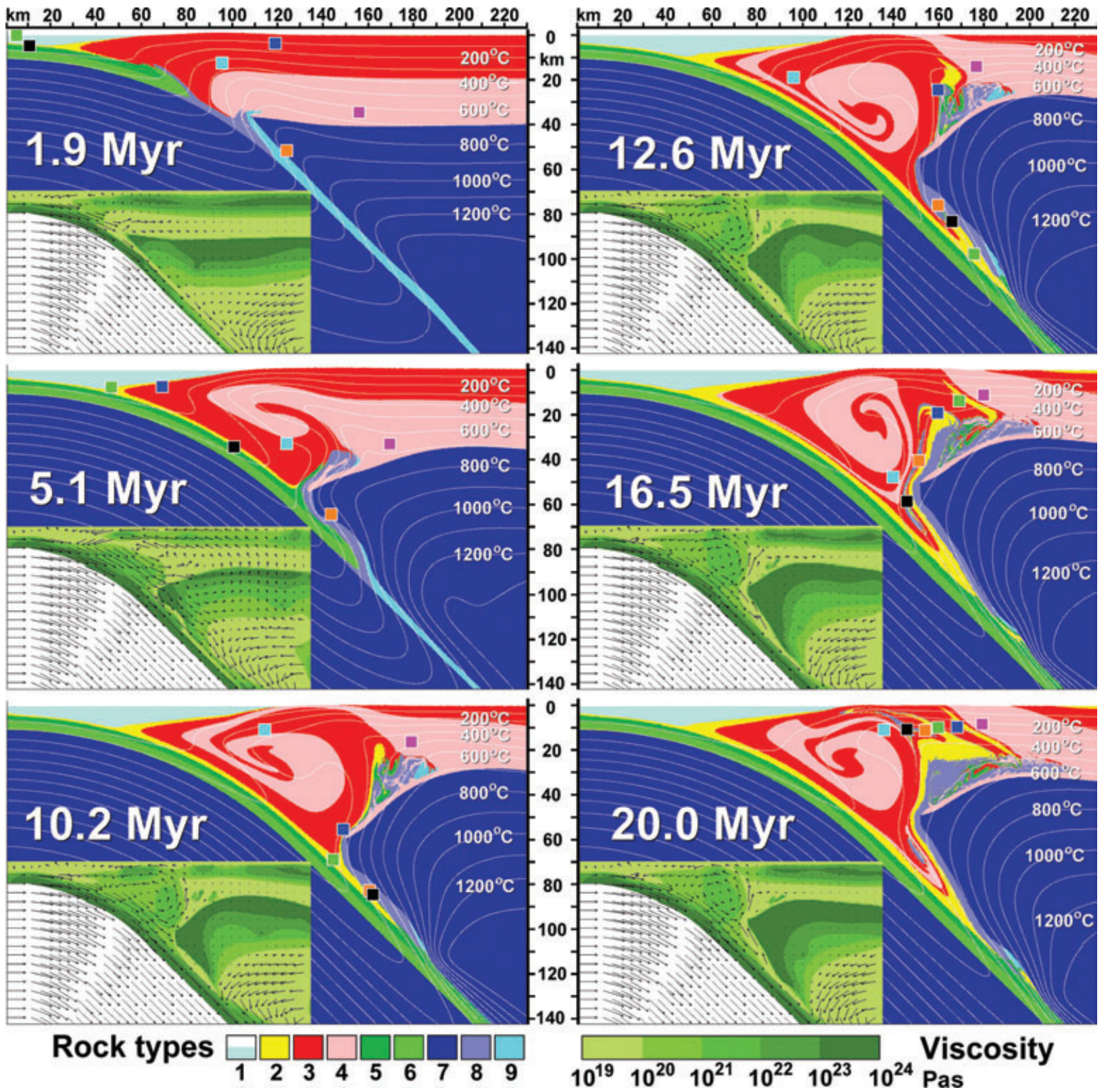

Fig. 2 Evolution of the active margin (model 'hyaa', parameters see Supplementary Material, Table S1) shown in six time slabs (1.9 Myr, 5.1 Myr, 10.2 Myr, 12.6 Myr, 16.5 Myr and 20 Ma). Rock types and materials are as follows: 1, weak surface layer (air, sea water); 2, sediments; 3 , upper continental crust; 4 , lower continental crust; 5 , upper oceanic crust; 6 , lower oceanic crust; 7 , dry mantle; 8 , serpentinized mantle; 9 , hydrated mantle. 
3 A megascale melange composed of HP and UHP metamorphic oceanic and continental crust, and hydrated mantle, intermingled and subsequently extruded from the subduction channel.

4 An upward tilted frontal part of the remaining lid, with exposed deeper levels of the overriding continental crust juxtaposed against zone $\mathrm{C}$.

The predicted $P-T$ time paths for representative volumes of crust, displayed for each time slab in Fig. 2, are compiled in Fig. 3. A simple scheme visualizing the characteristic trajectories, lithology and inferred large scale structures for the zones $\mathrm{A}$ to $\mathrm{D}$ is shown in Fig. 4.

\section{Discussion}

\section{Structure and particle trajectories}

Limitations in the simulation are because of the grossly simplified structure and the neglected inhomogeneities, particularly in the continental crust. In fact, the structure of a real orogenic belt may be largely controlled by prescribed heterogeneities and pre-existing zones of weakness, as for instance by faults developed previously during rifting of the continental margin. In addition, new discontinuities - as large scale faults - cannot develop in the present simulations. For instance, the boundary between zones $\mathrm{C}$ and $\mathrm{D}$, as defined above and shown in Fig. 4, is likely to develop more realistically as a fault similar to the so-called backthrust in the Alps (e.g. Escher and Beaumont, 1997; Ellis et al., 2001).

In the simulation shown here, continental material removed from the landward slope of the trench is continuously carried down beneath the forearc. This type of subduction erosion is documented at active continental margins showing little accretion worldwide (von Huene and Scholl, 1991). In our simulation, the process is enhanced by the chosen 'weak' rheology, supposed to be a fair approximation to the behaviour of continental crust in a forearc with continuous supply of fluid from the dewatering subducted crust underneath. Subduction erosion affects both upper and lower continental crust of the forearc, and material derived from both levels (discriminated by colour in Fig. 2) becomes stretched out and wound up as schlieren in the broad wedge (zone B). The schlieren on the crustal scale may be compared with metamorphic nappes, both with respect to thickness and aspect ratio. The characteristic length scale of intermingling between units of different provenience has been found to depend on the viscosity of the materials (Gerya et al., 2002), with higher viscosities leading to more extensive coherent nappe structures, and lower viscosities to a mega-scale melange-type pattern, as developed in the subduction channel and exposed in zone $\mathrm{C}$.

After circulation in the broad convolute wedge (zone B) and extrusion from the deep-reaching subduction channel (zone C) the structural grain is predominantly horizontal or shallow-dipping. Steep zones develop on the flanks of the marble cake wedge, with a convolute structure on a length scale of tens of kilometres, while the material extruded from the subduction channel spreads horizontally on the landward side of the convolute marble cake wedge and protrudes beneath the rear part of the lid. Such structures may be compared with the structures exposed in mountain belts.

\section{Time scales}

The time scales inherent in the simulated evolution are governed by the imposed plate velocity. For the chosen moderate convergence rate of $3 \mathrm{~cm} \mathrm{year}^{-1}$, the structure of the active margin develops within c. $20 \mathrm{Myr}$ and (U)HP metamorphic rocks become exposed at the surface a few million years later. Exposure at the surface is governed by the mechanical strength of the overriding continental crust, which - in the simulations - is controlled by the prescribed pore pressure coefficient. In the model shown here (Fig. 2) this is defined as 0.9, making the lid rather weak. A stronger lid, obtained by imposing a lower value for $\lambda$, would prevent the rapid uprise and relatively early surface exposure of the metamorphic wedge of zone B.

\section{$P-T$ paths}

The shape of the predicted $P-T$ paths corresponds to those typically inferred from thermobarometric analysis of exhumed HP and UHP metamorphic rocks (e.g. Spalla et al., 1996; Duchêne et al., 1997; Carswell and Zhang, 1999; Ernst and Liou, 1999; Ernst, 1999), although temperatures achieved in the simulation tend to be lower by approximately $100{ }^{\circ} \mathrm{C}$. Notably, some of the particle trajectories imply loops in the $P-T$ paths, for which an unequivocal record in natural rocks remains to be identified.

The position of the markers, for which the $P-T$ paths are shown in Figs 2 and 3, is chosen in such a way so as to represent a series of rocks closely spaced in a horizontal level, envisaged to represent a future postcollisional erosional land surface to be sampled by a geologist. This choice visualizes the contrast in the $P-T$ paths, as well as in the provenience of the protolith and the timing of peak metamorphism, which can be realized in immediately adjacent tectonic units or 'nappes' in an orogenic belt.

\section{Comparison with principal features of the European Alps}

Clearly, a 2D simulation starting with a simple lithospheric structure and with the assumption of a constant kinematic framework can only very poorly represent the actual evolution of an orogenic belt, like the European Alps, in three dimensions. In nature, the structure of an orogenic belt is generally supposed to be controlled by a very wide spectrum of pre-existing tectonic features, crustal structure and inherited lithospheric properties. Amazingly, comparing cross-sections of the European Alps with the results of the simulations shown in Fig. 5 nevertheless yield some similarity in the principal features. The relative width and the spatial arrangement, the provenience, the inferred structural and petrological record, and the simulated $P-T$ paths for materials in zones A to D, compare with the respective pattern in the Alps - within the limits outlined above.

First, it should be emphasized that the present day Alps are a collisional orogen, and large part of their deformation and structures are ascribed to the final collision between the passive European and the active overriding Apulian margin (e.g. Coward and 
(a)
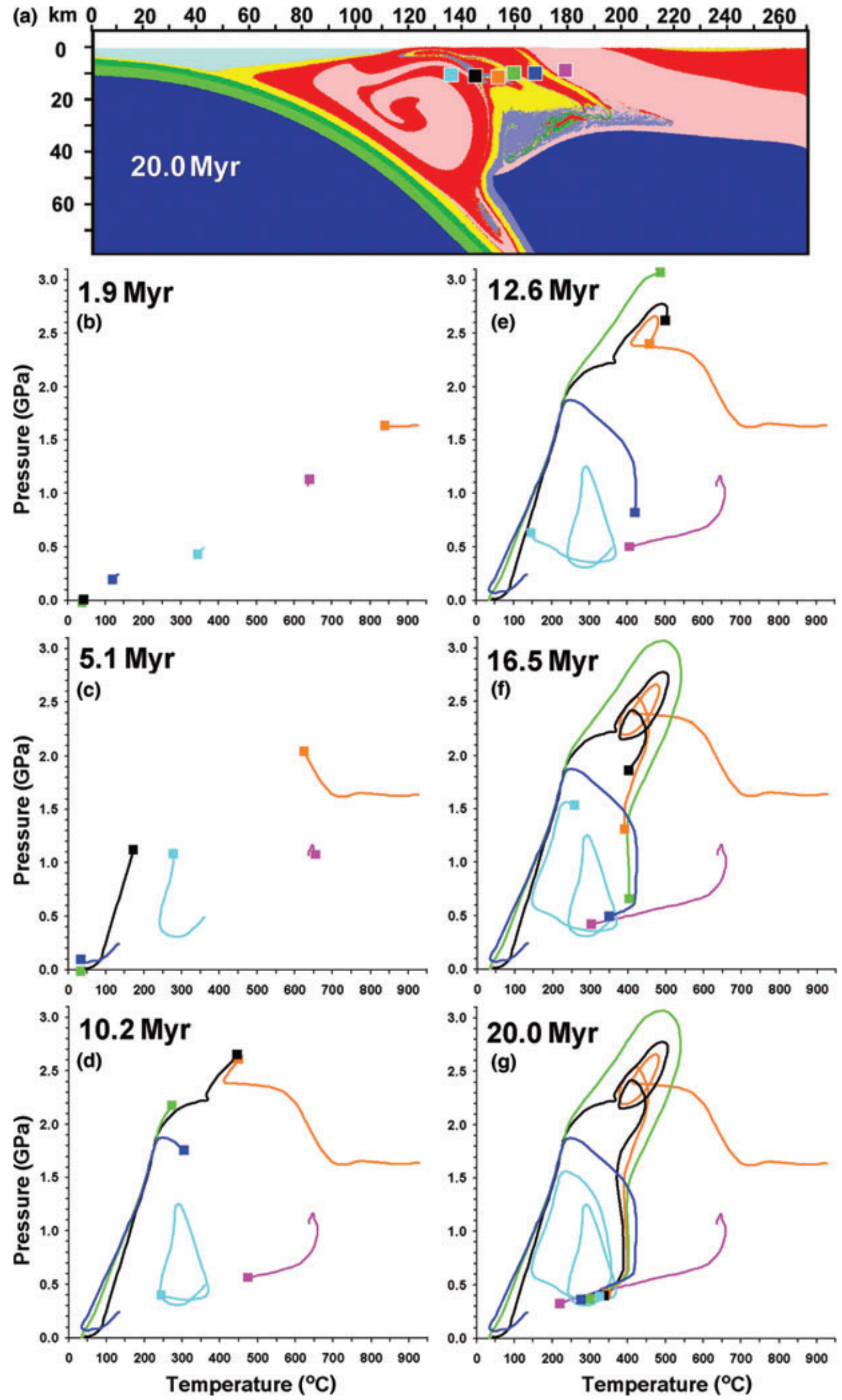


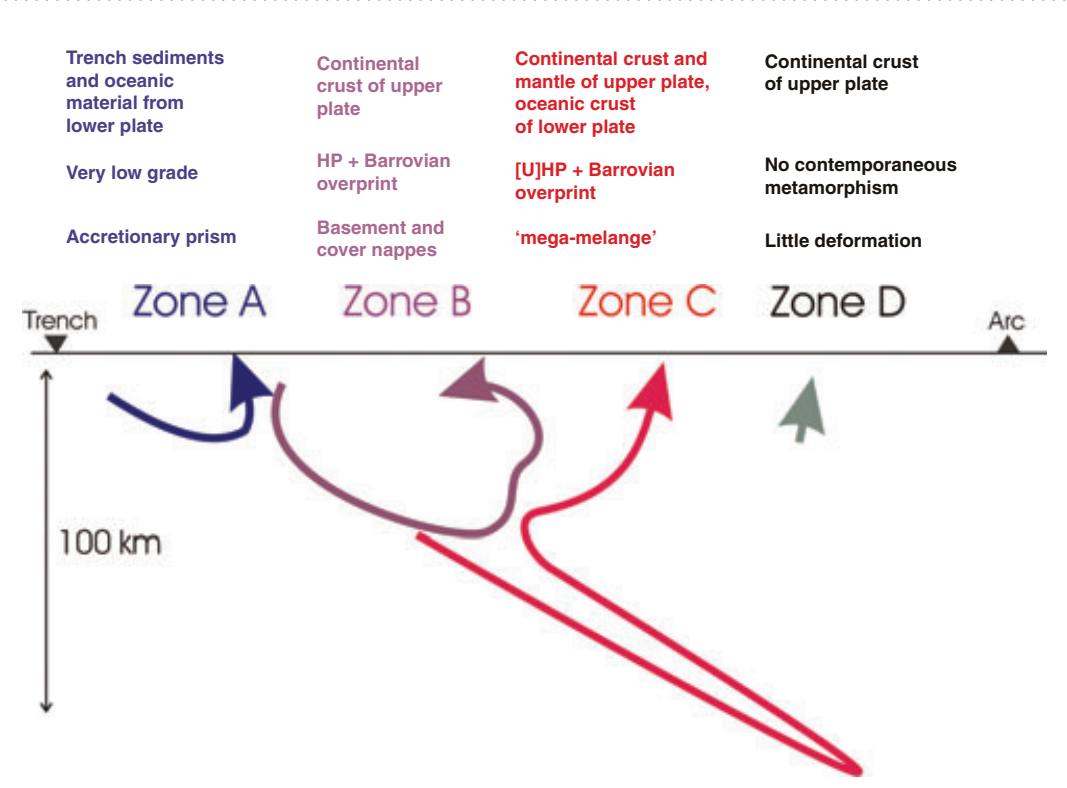

Fig. 4 Scheme visualizing the characteristic trajectories of geological units (zones A to D) in the subduction zone and position in the pre-collisional orogenic belt, with characteristic materials, metamorphism and structural record indicated.

Dietrich, 1989). Our simulation is terminated in a pre-collisional stage, while deformation during collision - with reference to the Alps - has been simulated in other studies (e.g. Escher and Beaumont, 1997; Pfiffner et al., 2000; Ellis et al., 2001).

In the Alps, the Penninic realm comprises metamorphic nappes of continental and oceanic material, with a broad variety of inferred palaeogeographical settings. The original arrangement of the Penninic units has been reconstructed from their present structural setting, and a pattern of oceanic troughs and microcontinents has been inferred (e.g. Trümpy, 1960; Debelmas et al., 1983; Coward and Dietrich, 1989; Schmid et al., 1996; Froitzheim, 2001). There is one major problem with these reconstructions, however. While oceanic lithosphere can be completely subducted, and only small remnant slices may mark the suture where a wide ocean has disappeared, the volume of continental crust that once made up a microcontinent needs to be stored somewhere. As discussed by Polino et al. (1990), there is a tremendous contrast in scale: the thickness of the Alpine nappes is typically on the order of a few kilometres (e.g. Laubscher, 1988), and the nappes can be traced over some tens of kilometres, with possibly further extrapolation to depth based on reflection seismic profiles (e.g. Schmid et al., 1996). In contrast, the minimum horizontal dimensions of a microcontinent embedded in oceanic realms, with the respective passive margins, are likely to be in the range of several tens to hundreds of kilometres. More importantly, the thickness of the continental crust in such slivers embedded in oceanic crust can be expected to be at least $20-30 \mathrm{~km}$, which results in a volume of continental crust exceeding that of the typical Alpine basement nappes by one to two orders of magnitude (Polino et al., 1990). Thus, palaeogeographical restorations seem to be at odds with the actual volume of continental crust preserved in the Alps.

Polino et al. (1990) have proposed that this discrepancy can be resolved when one accepts that the continental parts of the Penninic nappes can be derived from the front of the overriding plate by subduction erosion (also referred to as tectonic erosion), widely established for active continental margins (Von Huene and Scholl, 1991). If so, there would be no constraints on the volume of the individual coherent nappes. In addition, the tectonic units can be derived from any level of the crust of the overriding continent, not necessarily in a systematic sequence related to palaeogeography. The continent-derived Penninic nappes are separated by oceanic slices, made up by both dismembered ophiolites with extensive volumes of serpentinized mantle perdidotites (e.g. the Zermatt Saas Zone), and nappes largely composed of metasediments (e.g. the Combin Zone), with widely varying peak metamorphic conditions ranging from blueschist facies to eclogite facies, and with UHP metamorphism recorded in both former oceanic (e.g. Reinecke, 1998) and continental crust (e.g. Chopin et al., 1991).

Derivation of the continental slices by subduction erosion, and pre-collisional circulation through either a wide more frontal wedge (to finally end up in zone B in our simulation) or a deep narrow subduction channel (to end up in zone $\mathrm{C}$ ), leaves many degrees of freedom for their intermingling with oceanic slices and sedimentary material deposited on both oceanic or thinned continental crust, characteristic for the internal Penninic nappes in the Alps. Moreover, contrasting $P-T$ paths with highly

Fig. $3 P-T-t$ paths of rocks indicated as markers in Fig. 2. The black marker represents oceanic crust that passes the trench at 2.5 Myr (referring to the start of the simulation); the green marker oceanic or trench sediment situated at the trench axis at 4.5 Myr; the orange marker mantle material situated at a depth of $70 \mathrm{~km}$ immediately atop the prescribed weak zone which determines the future position of the slab. The other three markers represent continental crust of the overriding plate. The turquoise marker represents continental crust situated at approximately $20 \mathrm{~km}$ depth, in a deep level of the upper crust, and is situated about $70 \mathrm{~km}$ from the developing trench at $1 \mathrm{Myr}$; the blue marker represents a shallow level of the upper crust situated about $100 \mathrm{~km}$ from the developing trench at $1 \mathrm{Myr}$; and the pink marker lower continental crust, situated at about $40 \mathrm{~km}$ depth and $130 \mathrm{~km}$ from the developing trench at $1 \mathrm{Myr}$. Note how the $P-T$ paths converge towards time slab $20 \mathrm{Myr}$, corresponding to the position of the markers being closely arranged in space in Fig. $2 \mathrm{f}$. The arrangement is chosen to simulate a specific level of erosion that could be attained subsequent to an eventual continental collision shortly after the 20 Myr time slab. 
(a)

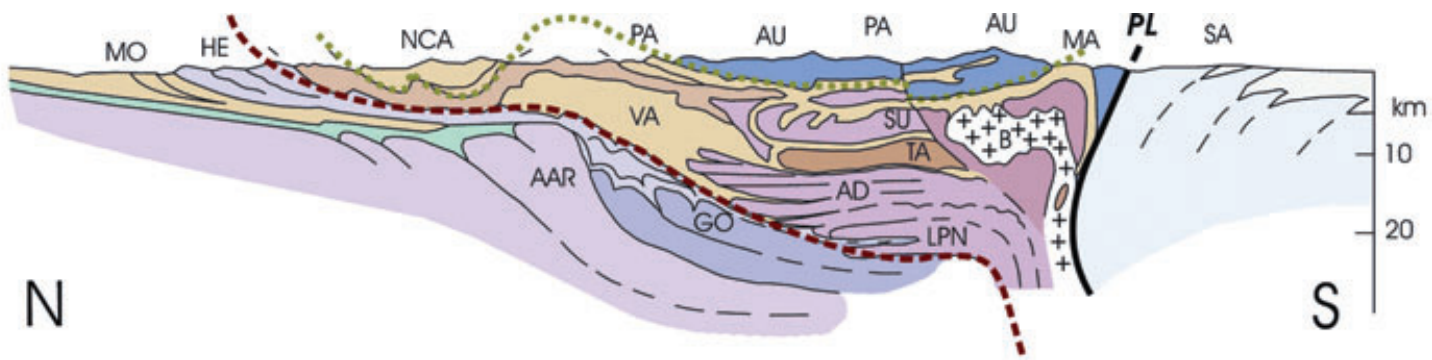

(b)

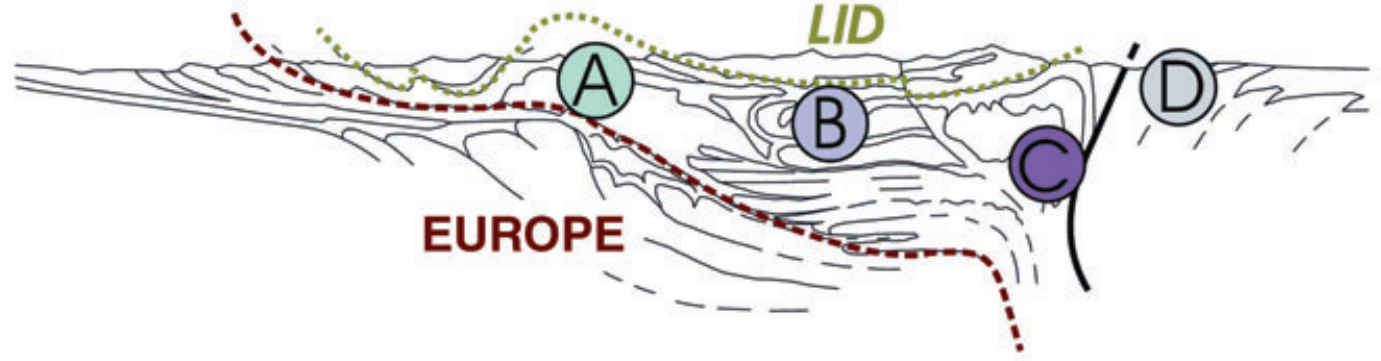

(c)

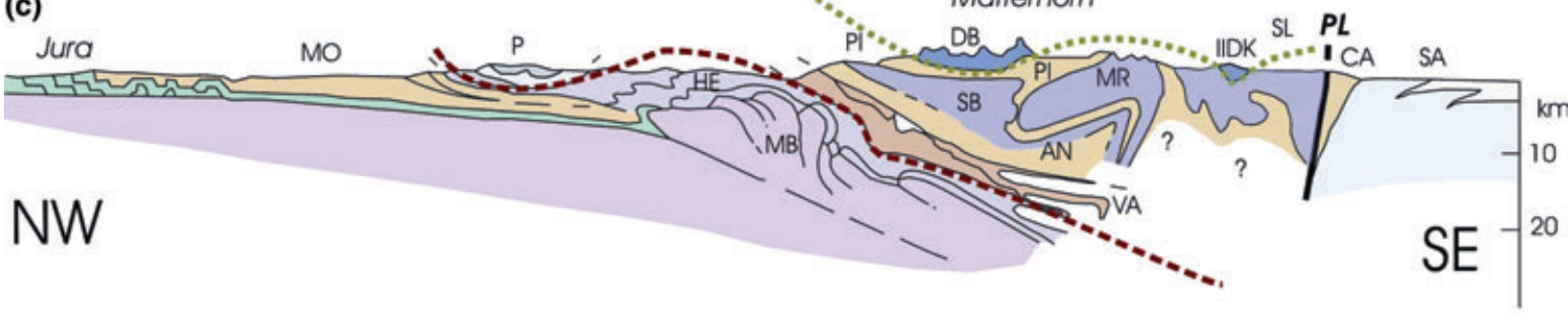

(d)

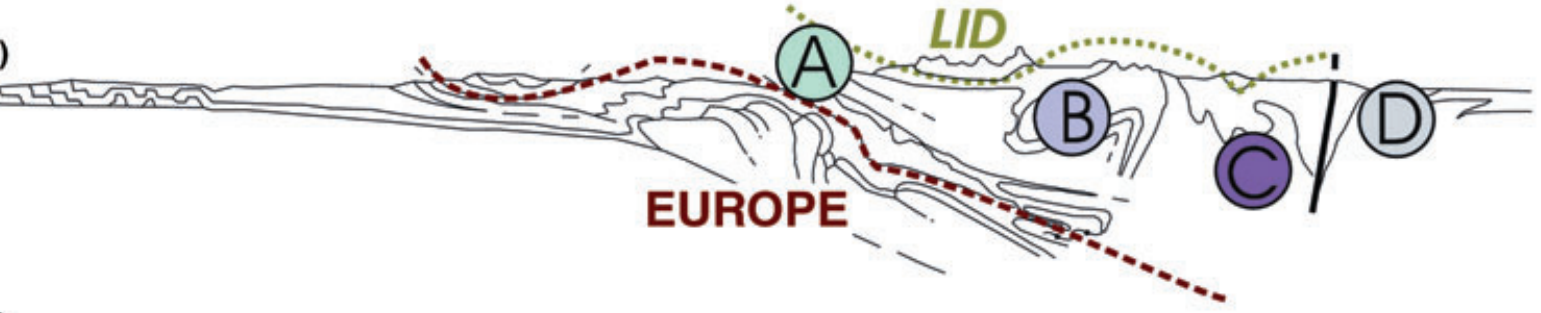

(e)

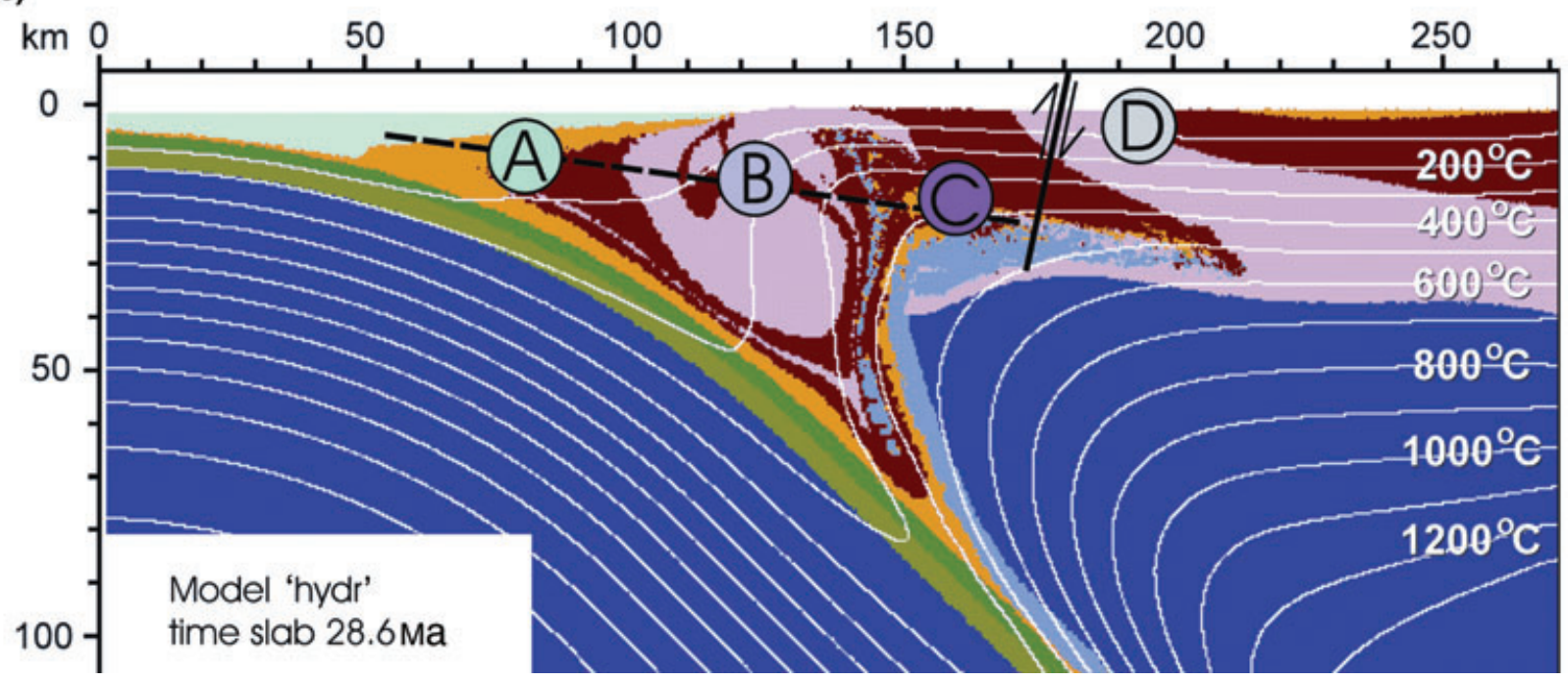


variable early HP metamorphic records (e.g. Spalla et al., 1996) and rather uniform later greenschist facies overprint in adjacent units are well documented for the Alps, and are also observed in the simulations. Based on the simulation, a pre-collisional structure similar to that shown in Fig. 5 can be envisaged for the Alps, with zone A corresponding to the external low grade metamorphic nappes (e.g. Arosa Zone), zone B to the blueschist and eclogite bearing Penninic nappes (e.g. Bernhard Nappe), zone $\mathrm{C}$ to the more internal (U)HP metamorphic oceanic and continental slices with intermingled serpentinites (e.g. Zermatt Saas Zone and Dora Maira Massif; understood as a megascale melange or involuted melange; Hsü, 1989), and finally zone $\mathrm{D}$ to the southern Alps, with the northernmost section warped up and an unmetamorphic Permian to Mesozoic sedimentary cover preserved further to the south.

\section{Conclusions}

1 High pressure metamorphic continental crust in orogenic belts needs not be ascribed to the downgoing plate, but can be derived by subduction erosion from the active continental margin; hence, (U)HP metamorphism of continental material does not unequivocally indicate collision.

2 Large parts of the material removed by subduction erosion become wound up in a marble cake fashion in a broad wedge beneath the forearc, forming alternating nappes of lower and upper crustal provenance.

3 Material carried further down into the subduction channel mixes up with oceanic and hydrated mantle material and partly returns by forced flow. It becomes extruded on the landward side of the marble cake wedge, forming a megascale melange of HP and UHP nappes with contrasting $P-T$ paths.

4 The kinematic patterns arising in our simulations suggest that palaeogeographical reconstructions based on the vertical sequence of metamorphic nappes in orogenic belts may need critical re-evaluation.

5 Derivation of slices of continental crust by subduction erosion from the upper plate margin, and not from microcontinents in the downgoing plate, may resolve the problem of the discrepancy between the volume of continental crust required by palaeogeographical reconstructions and the actual volume stored in orogenic belts.

6 Finally, the metamorphic nappe structure in the internal realm of an orogenic belt - like the Alps may develop largely prior to collision. For the Alps, such a pre-collisional mountain building process was previously discussed in much detail by Polino et al. (1990); their hypotheses are supported by the results of our simulations.

\section{Acknowledgements}

Funding by the German Science Foundation within the scope of collaborative research centre SFB 526 'Rheology of the Earth - from the upper crust into the subduction zone', by the Alexander von Humboldt Foundation, by the Russian Foundation of Basic Research (grant numbers 03-05-64633 and 1645-2003-5), and by ETH research grant TH-12/04-1 to T.V.G. is gratefully acknowledged. Two anonymous referees are thanked for their constructive comments.

\section{Supplementary material}

The following material is available at http://www.blackwellpublishing. com/products/journals/suppmat/TER/ TER589/TER589sm.htm:

Appendix S1 Model design and numerical technique.

Figure S1 Initial configuration, starting and boundary conditions of our numerical simulation of an active continental margin.

Fig. 5 Two simplified cross sections through the central (a) and western (c) Alps, slightly modified after Polino et al. (1990), compared with the final $(28.6 \mathrm{Ma})$ time slab of numerical simulation 'hydr' (e). The distribution of the four zones with characteristic deformation patterns and $P-T-t$ paths recognized in the simulation (Figs 2 and 3 ) and schematically visualized in Fig. 4 are tentatively marked in the unlabelled Alpine sections shown in (b) and (d). The green dashed line in the Alpine cross sections marks the base of the rigid upper portion of the overriding continental crust, referred to as lid, and the red dashed line the upper boundary of the European continent that entered the scene upon collision. The pre-collisional structure developed in our simulation is to be compared with the Alpine crustal structure above the red dashed line. The boundary between zones $\mathrm{C}$ and D may be compared with the backthrust of the Insubric fault (e.g. Ellis et al., 2001), separating the southern (innermost) Penninic units (compared with zone C) from the southern Alps (compared with zone D). Zone C comprises intermingled (on a nappe scale) continental, oceanic, and mantle material with widespread HP and UHP metamorphic record, as observed in the southern Penninic Units, e.g. the Zermatt Saas Zone or the Dora Maira Massif. Zone B can be compared with the Penninic units of the Bernhard Nappe, the Lepontine Nappes, or the central gneisses of the Tauern Window in the Eastern Alps, with a nappe structure engulfing former deeper and upper continental crust (including a sedimentary cover) and early stages of high pressure metamorphism (e.g. Heinrich, 1982) overprinted by later greenschist or amphibolite facies metamorphism. Zone A, which is more extensively developed in the 'hydr' simulation shown here, when compared with model 'hyaa' shown in Fig. 2 , may be compared with the external Penninic units exposed in the Arosa Zone or the Lower Engadine Window in the Central and Eastern Alps respectively. Note that the simulation was neither designed to reproduce the Alpine history, nor can the structure of the Alps be represented by a 2D model; also it is probably governed by pre-existing crustal heterogeneity, not accounted for in the model. Labels in the Alpine cross sections (Polino et al., 1990) are as follows: LPN, Lower Penninic Nappes; AD, Adula Nappe; SU, Suretta Nappe; MR, Monte Rosa Nappe; SB, Grand St. Bernard Nappe and Brianconnais; AU, Austroalpine ('LID', thrusted Apulian basement and cover); SA, Southern Alps (Apulian basement and cover); CA, Canavese Zone; GO, TV, AAR, MB, Gotthard, Tavetsch, Aar, Mont Blanc Massifs (European basement); HE, Helvetic nappes (European cover); MO, Molasse, PA, MA, PI, AN, Platta-Arosa, Malenco-Avers, Piedmont, Antrona ophiolitic units; P, Prealpine décollement nappes; VA, Valais ophiolitic and flysch units; B, Bergell intrusives (Oligocene); PL, Periadriatic Lineament (Insubric fault). 
Table S1 Material properties used in 2-D numerical experiment hyaa.

\section{References}

Burov, E., Jolivet, L., Le Pourhiet, L. and Poliakov, A., 2001. A thermomechanical model of exhumation of high pressure (HP) and ultra-high pressure (UHP) metamorphic rocks in Alpine-type collision belts. Tectonophysics, $\mathbf{3 4 2}$, 113-136.

Carswell, D.A. and Zhang, R.Y., 1999. Petrographic characteristics and metamorphic evolution of ultrahigh-pressure eclogites in plate-collision belts. Int Geol. Rev., 41, 781-798.

Chemenda, A.I., Mattauer, M., Mattavieille, J. and Bokun, A.N., 1995. A mechanism for syn-collisional rock exhumation and associated normal faulting: results from physical modelling. Earth Planet. Sci. Lett., 132, 225-232.

Chopin, C., 2003. Ultrahigh pressure metamorphism: tracing continental crust into the mantle. Earth Planet. Sci. Lett., 212, 1-14.

Chopin, C., Henry, C. and Michard, A., 1991. Geology and petrology of the coesite-bearing terrain, Dora Maira Massif, western Alps. Eur. J. Mineral., 3, 263-291.

Coward, M.P. and Dietrich, D., 1989. Alpine tectonics - an overview. In: $\mathrm{Al}$ pine Tectonics (M.P. Coward, D. Dietrich and R.G. Park, eds). Geol. Soc. Lond. Spec. Publ., 45, 1-29.

Debelmas, J., Escher, A. and Trümpy, R., 1983. Profiles through the western Alps. In: Profiles of Orogenic Belts (N. Rast and F.M. Delaney, eds). Am. Geophys. Union Geodyn. Ser., 10, 83-96.

Duchêne, S., Lardeaux, J.-M. and Albarède, F., 1997. Exhumation of eclogites: insight from depth-time path analysis. Tectonophysics, 280, 125-140.

Eide, E.A. and Liou, J.G., 2000. Highpressure blueschists and eclogites in Hong'an: a framework for addressing the evolution of high- and ultrahigh- pressure rocks in central China. Lithos, 52, 1-22.

Ellis, S., Wissing, S. and Pfiffner, A., 2001. Strain localization as a key to reconciling experimentally derived flow-law data with dynamic models of continental collision. Int. J. Earth Sci., 90, 168-180.

Ernst, W.G., 1999. Metamorphism, partial preservation, and exhumation of ultrahigh-pressure belts. Island Arc, $\mathbf{8}$, 125-153.

Ernst, W.G. and Liou, J.G., 1999. Overview of UHP metamorphism and tectonics in well-studied collisional orogens Int. Geol. Rev., 41, 477-493.

Escher, A. and Beaumont, C., 1997. Formation, burial and exhumation of basement nappes at crustal scale: a geometric model based on the western Swiss-Italian Alps. J. Struct. Geol., 19, 955-974.

Froitzheim, N., 2001. Origin of the Monte Rosa Nappe in the Pennine Alps - a new working hypothesis. Geol. Soc. Am. Bull., 113, 604-614.

Gerya, T.V., Yuen, D.A., 2003a. RayleighTaylor instabilities from hydration and melting propel "cold plumes" at subduction zones. Earth Planet. Sci. Lett., 212, 47-62.

Gerya, T.V., Yuen, D.A., 2003b. Characteristics-based marker-in-cell method with conservative finite-differences schemes for modeling geological flows with strongly variable transport properties. Phys. Earth Planet. In., 140, 295-320.

Gerya, T.V., Perchuk, L.L., van Reenen, D.D. and Smit, C.A., 2000. Twodimensional numerical modeling of pressure-temperature-time paths for the exhumation of some granulite facies terrains in the Precambrian. J. Geodyn., 30, 17-35.

Gerya, T.V., Stöckhert, B. and Perchuk, A.L., 2002. Exhumation of high-pressure metamorphic rocks in a subduction channel - a numerical simulation. Tectonics, 21, 6-1-6-19.

Hacker, B.R. and Liou, J.G., 1998. When Continents Collide: Geodynamics and Geochemistry of Ultrahigh-Pressure
Rocks. Kluwer Academic Publishers, Dordrecht.

Heinrich, C.A., 1982. Kyanite-eclogites to amphibolite facies evolution of hydrous mafic and pelitic rocks, Adula Nappe, Central Alps. Contrib. Mineral. Petrol., 81, 30-38.

Hsü, K.J., 1989. Time and place in Alpine tectonics - the Fermor lecture. In: Alpine tectonics (M.P. Coward, D. Dietrich and R.G. Park, eds). Geol. Soc. Lond. Spec. Publ., 45, 421-443.

von Huene, R. and Scholl, D.W., 1991. Observations at convergent margins concerning sediment subduction, subduction erosion, and the growth of continental crust. Rev. Geophys., 29, 279-316.

Laubscher, H.P., 1988. Material balance in Alpine orogeny. Geol. Soc. Am. Bull., 100, 1313-1328.

Pfiffner, O.A., Ellis, S. and Beaumont, C., 2000. Collision tectonics in the Swiss Alps: insight from geodynamic modelling. Tectonics, 19, 1065-1094.

Polino, R., Dal Piaz, G.V. and Gosso, G., 1990. Tectonic erosion at the Adria margin and accretionary processes for the Cretaceous orogeny of the Alps. Mem. Soc. Geol. France, 156, 345-367.

Reinecke, T., 1998. Prograde high- to ultrahigh pressure metamorphism and exhumation of oceanic sediments at Lago di Cignana, Zermatt-Saas Zone, western Alps. Lithos, 42, 147-189.

Schmid, S.M., Pfiffner, O.A., Froitzheim, N., Schönborn, G. and Kissling, E., 1996. Geophysical-geological transect and tectonic evolution of the Swiss-Italian Alps. Tectonics, 15, 1036-1064.

Spalla, M.I., Lardeaux, J.-M., Dal Piaz, G.V., Gosso, G. and Messiga, B., 1996. Tectonic significance of Alpine eclogites. J. Geodyn., 21, 257-285.

Trümpy, R., 1960. Paleotectonic evolution of the central and western Alps. Geol. Soc. Am. Bull., 71, 843-908.

Received 30 March 2004; revised version accepted 2 September 2004 